\title{
Glacial lake outburst flood hazard assessment by satellite Earth observation in the Himalayas (Chomolhari area, Bhutan)
}

\author{
Cristian Scapozza ${ }^{1}$, Christian Ambrosi $^{1}$, Massimiliano Cannata ${ }^{1}$, and Tazio Strozzi ${ }^{2}$ \\ ${ }^{1}$ Institute of Earth Sciences, University of Applied Sciences and Arts of Southern Switzerland (SUPSI), \\ Campus Trevano, 6952 Canobbio, Switzerland \\ ${ }^{2}$ Gamma Remote Sensing, Worbstrasse 225, 3073 Gümligen, Switzerland \\ Correspondence: Cristian Scapozza (cristian.scapozza@supsi.ch)
}

Received: 23 April 2018 - Revised: 26 February 2019 - Accepted: 14 March 2019 - Published: 28 March 2019

\begin{abstract}
A case study of glacial lakes outburst flood (GLOF) hazard assessment by satellite Earth observation (EO) and numerical modelling is presented for the supraglacial and ice-contact lakes on Thangothang Chhu glacier, Chomolhari area (Bhutan). Detailed geomorphological mapping, including landslide and rock glacier inventories, as well as surface displacement determination using an interferometric SAR (InSAR) satellite, allowed a GLOF hazard assessment for lake Wa-007 to be performed. Outburst scenario modelling was achieved by combining both empirical and numerical modelling approaches, revealing that only a flood wave can have an impact on the two human settlements located downslope of Wa-007 lake. The worst-case scenario, modelled thanks to r.damflood, allowed the wave-front arrival time, the maximum water depth and the arrival time of maximum water height for the two human settlements to be quantified. A long-term monitoring strategy based entirely on EO data, with an update cycle of 5 years, is proposed to assess the future evolution of the area.
\end{abstract}

\section{Introduction}

Thanks to satellite Earth observation (EO), hazard assessments of glacial lake outburst floods (GLOFs) were performed in several mountain chains of the world, including the Alps (e.g. Haeberli, 1983; Huggel et al., 2004; Haeberli et al., 2001), the Andes (e.g. Schneider et al., 2014; Schaub et al., 2015; Frey et al., 2016) and the Himalayas (e.g. Budhathoki et al., 2010; Haemmig et al., 2014) in the last years. Due to its extension, importance in the south-Asiatic geopolitical context and natural sensitivity to climate change, the Himalayas were recently of great interest in research projects related to landslide- (e.g. Ambrosi et al., 2018) and glacierrelated (e.g. Allen et al., 2016) hazard assessments, including morphological studies trying to quantify future lake formation by glacier melting (e.g. Schaub et al., 2013; Linsbauer et al., 2016) or quantify permafrost degradation (e.g. Gruber et al., 2017). In this framework, the GLOF hazard assessment is to be considered to be a part of the general topic concerning the connection between high-mountain hazards and climate change (e.g. GAPHAZ, 2017), which integrates the impact of permafrost degradation on the stability of rock slopes above glaciers (e.g. Gruber and Haeberli, 2007; Krautblatter et al., 2013) or the increasing hazard related to ice-rock avalanches falling into new lakes from icy peaks with degrading permafrost (e.g. Salzmann et al., 2004; Haeberli et al., 2017).

This paper presents a GLOF hazard assessment for the supraglacial lake Wa-007 on the Thangothang Chhu glacier, Chomolhari area in the Bhutan Himalayas. This assessment was carried out in the framework of a European Space Agency-World Bank (ESA-WB) collaboration project on satellite EO in the Himalayas, where landslides, floods and GLOF hazard assessments were performed in Nepal and Bhutan (Sauerbier et al., 2015a; Scapozza, 2015; Ambrosi et al., 2018). Within this framework, the GLOF hazard assessment has made it possible to combine observations from flood and landslide hazard mapping, as well as to valorise the products derived from land use and land cover mapping and from the generation of high-resolution digital-elevation models (DEMs). 


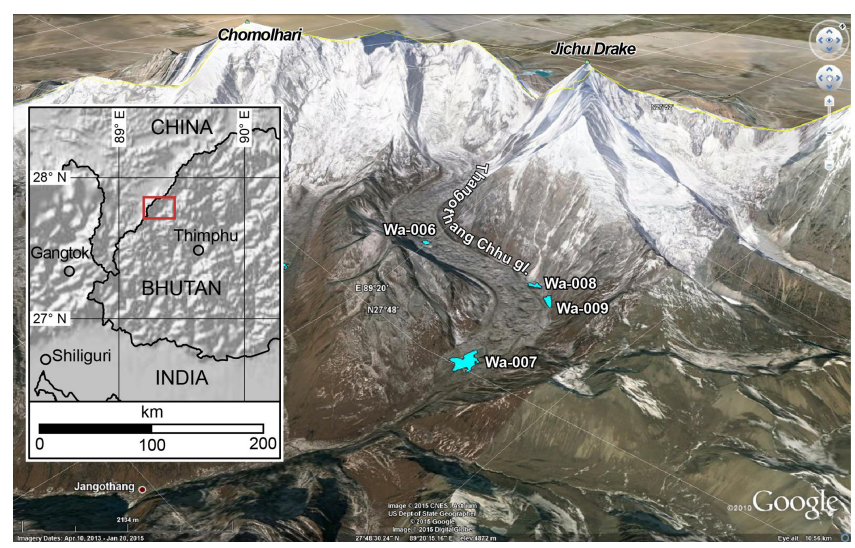

Figure 1. Google Earth image with the Glacial Lake Inventory of Bhutan using ALOS (Daichi) data (light blue) (GLIB, 2000). The supraglacial lake object of this assessment report is Wa-007.

\section{Study area}

\subsection{Site description}

The Chomolhari area is located in north-western Bhutan, in the Thimphu District (Thimphu is also the capital of Bhutan and the largest city of the state) and a few kilometres north of the village of Jangothang (Fig. 1). Chomolhari (7326 m a.s.l., also known as Jomolhari or Chomo Lhari) is the second highest peak in Bhutan, lying on the western border with Tibet.

According to the climate diagram based on 30 years of hourly weather model simulations on the Chomolhari area and calculated for the $4156 \mathrm{~m}$ a.s.l. of Jantogang Camp (Meteoblue, 2018), the sum of annual precipitation is $317 \mathrm{~mm}$. Minimum temperatures during cold nights can reach $-21^{\circ} \mathrm{C}$ in January, whereas maximum temperatures during hot days can reach $17^{\circ} \mathrm{C}$ in summer. Mean daily minimum temperature is between $-13{ }^{\circ} \mathrm{C}$ in January and $3{ }^{\circ} \mathrm{C}$ in July (mean annual value of $-4.5^{\circ} \mathrm{C}$ ) and mean daily maximum temperatures is between $0{ }^{\circ} \mathrm{C}$ in January and February and $14^{\circ} \mathrm{C}$ in summer (mean annual value of $7.75^{\circ} \mathrm{C}$ ). Mean annual air temperature (MAAT) is then $1.6^{\circ} \mathrm{C}$. Considering a mean rate lapse of $0.6^{\circ} \mathrm{C} 100 \mathrm{~m}^{-1}$, the $0^{\circ} \mathrm{C}$ MAAT is located at about $4420 \mathrm{~m}$ a.s.l. As a rough estimation from Google Earth images, the equilibrium line altitude (ELA) on glaciers is at about $5500-5700 \mathrm{~m}$ a.s.l. for south and south-east expositions; this corresponds to a MAAT at the ELA of about -6.5 to $-7.7^{\circ} \mathrm{C}$. Concerning the permafrost distribution, Gruber (2012) tried to derivate a high-resolution estimation of permafrost zonation, whereas Gruber et al. (2017) reviewed the importance of permafrost degradation in the Hindu Kush region of Himalayas.

The glacial lake object of this assessment report, Wa-007 according to the glacial and glacial lake inventory of Bhutan (GLIB, 2000), is located in the frontal part of the $8.5 \mathrm{~km}$ long debris-covered glacier that originated from the glacial basin located on the south-western part of Jichu Drake

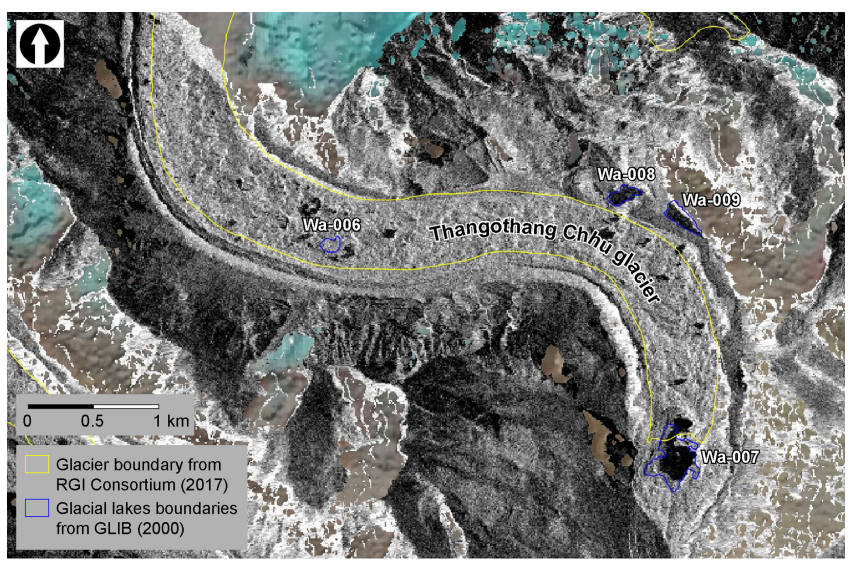

Figure 2. TerraSAR-X backscattering intensity image of 2 June 2014 showing many supraglacial ponds in black. The names of the lakes are according to GLIB (2000).

peak (6790 $\mathrm{m}$ a.s.1.). This glacier will be named Thangothang Chhu glacier, according to the river generated at this front (RGI Consortium, 2017). The Wa-007 lake lies directly on the Thangothang Chuu debris-covered glacier and can be considered as a supraglacial lake. Several other small supraglacial lakes are present on the Thangothang Chhu glacier (the second biggest lake is Wa-006), as shown in Figs. 1 and 2. Two other important ice-contact lakes are present on the northern side of the glacier, outside of its historical moraine ridges (lakes Wa-008 and Wa-009).

The main settlements present on the valley starting from the Chomolhari area is the town of Paro (ca. 20000 inhabitants), located about $50 \mathrm{~km}$ from the Thangothang Chhu glacier tongue. Closest to the glacier lake area, only two settlements are present. Jantogang Camp (4150 m a.s.l.) is located at $2.5 \mathrm{~km}$ and the village of Jangothang (4000 m a.s.1.) at $4.2 \mathrm{~km}$ downslope of the Wa-007 lake. No other human settlements are present downslope of Jangothang for more than $20 \mathrm{~km}$. Jantogang Camp is the base camp for hiking and climbing in the Bhutan part of Chomolhari area and is composed of three sparse permanent buildings (visible in Google Earth) and by a variable number of tents according to the season. The village of Jangothang presents 16 buildings (also visible in Google Earth) located on two fluvial terraces of the Thangothang Chhu River and several livestock fences. Several other very small hamlets and isolated buildings are located on the valley floor up to $4 \mathrm{~km}$ downslope of the main settlement.

\subsection{Historical events}

On the glaciological mapping in 1962 by Reynolds (2000), the two main ice-contact lakes (Wa-008 and Wa-009) were already present, whereas the supraglacial lake Wa-007 on the terminal part of the Thangothang Chhu glacier was absent. In contrast to other Bhutan glacial lakes (see Richard- 
son and Reynolds, 2000; Nayar, 2009), there is no historical information about past events on the Thangothang Chhu glacier. In the scientific literature, the surface gradients of this glacier were analysed by Reynolds (2000) to explain the formation of supraglacial lakes on debris-covered glaciers, resulting from the stagnation of very slow-moving ice (negative mass balance) with surface gradients lower than $2^{\circ}$ and highlighting the supraglacial lake formation since 1966.

\section{Material and methods}

\subsection{Satellite EO mapping}

Detailed geomorphological mapping took place by combining three EO base maps and considering the pros and cons of every product. Direct mapping of geomorphological units was done on a VHRO KOMPSAT-2 orthophoto from 27 November 2010, with a ground resolution of $2 \mathrm{~m}$. Shape reconnaissance was improved thanks to hillshades of TanDEM-X DEM, with absolute and relative vertical accuracies of 5 and $2 \mathrm{~m}$ (Ambrosi et al., 2018). The joint use of orthophotos and hillshaded DEMs for geomorphological mapping, as well as the differentiation of slope, slope foot, glacial, glaciofluvial and periglacial landforms and deposits, was done according to the recommendations of Ambrosi and Scapozza (2015). Google Earth images were used as ancillary information for supporting the direct mapping and for the interpretation of the lake level fluctuations.

Satellite interferometric SAR (InSAR) - using both differential interferometric SAR (DInSAR, e.g. Bamler and Hartl, 1998) and persistent scatterer interferometry (PSI, e.g. Ferretti et al., 2001) - was used to assess the surface displacements. DInSAR has been applied to stacks of TerraSARX (Fig. 2), Sentinel-1, ERS-1/2 SAR, ENVISAT ASAR, ALOS-1 PALSAR-1 and Radarsat-2 images acquired between 1998 and 2015 from ascending and descending orbits. PSI analysis was conducted only with the stacks of ENVISAT ASAR images of the descending orbit and of ALOS1 PALSAR-1 images of the ascending orbit, because for the other image stacks the number of acquisitions was not sufficient for this kind of processing. For details about satellite SAR acquisitions, processing and interpretation please refer to Ambrosi et al. (2018). The complete set of images and data available for GLOF hazard assessment in the Chomolhari area is listed in Table 1.

Landslide and rock glacier inventories, comprising degrees of activity, were created from the joint analysis of detailed geomorphological mapping and of surface displacement rates quantified from InSAR, as described in detail by Ambrosi et al. (2018). Ice surface velocities were computed using offset tracking (Strozzi et al., 2002; Paul et al., 2015).

\subsection{Hazard assessment}

The GLOF hazard assessment was performed based on the checklist for glacier lake hazard assessments provided by the ESA's S:GLA:MO project (Frey et al., 2015). The S:GLA:MO project (Slope Stability and Glacial Lake Monitoring, http://sglamo.gamma-rs.ch, last access: 7 January 2019), funded by ESA and conducted between 2014 and 2015 by Gamma Remote Sensing (Switzerland), the Department of Geography of the University of Zürich (Switzerland), the Department of Geosciences of the University of Oslo (Norway) and Asiaq (Greenland) aimed to assess the hazard potential of glacial lakes based on EO data and products, in situ data and flow modelling. An integrated assessment of hazards related to glacial lakes was developed that address the widely acknowledged dependencies, integrated detection, monitoring and modelling of glacial lakes together with detection, monitoring and modelling of slope instabilities and glacier conditions and behaviour that potentially affect the glacial lakes. In order to provide a reproducible and transparent hazard assessment, the generic checklist-like structure was followed, according to which the analyses were conducted for the specific study case.

\subsection{Potential outburst scenarios modelling}

Two kinds of models were applied to the potential outburst scenario defined on the basis of the hazard assessment. The first one is based on empirical relationships proposed by Huggel et al. $(2002,2004)$ and Huggel (2004). Because the equation for lake volume quantification as proposed by Huggel et al. (2002: 31) and Huggel et al. (2004: 1069) is based on self-correlation relating the mathematical products between lake area and lake depth and the factor (the lake area) from which this product had been calculated, here we made a lake volume estimation $[V]$ based on the mean depth $[D]$, which was determined as follows starting from the lake surface [A] (Huggel et al., 2002: 319):

$D=0.104 \times A^{0.42}$.

In the case of ice-dammed lakes, the probable maximum discharge $\left[Q_{\max }\right]$ is a function of the volume $[V]$. Regarding subglacial drainage of ice-dammed lakes, $Q_{\max }$ can be calculated as follows (Huggel et al., 2004: 1071):

$Q_{\max }=46 \times\left(\frac{V}{10^{6}}\right)^{0.66}$.

The maximum discharge $\left[Q_{\max }\right]$ for a worst-case scenario, related to the ice dam suddenly breaking, is calculated by assuming mean drainage duration $[t]$ of $1000 \mathrm{~s}$ for maximum estimates as proposed in Haeberli's (1983) empirical relationship (Huggel et al., 2004: 1071).

$Q_{\max }=\frac{V}{t}$ 
Table 1. Data available for this hazard assessment of the Chomolhari area processed within this study and additional sources.

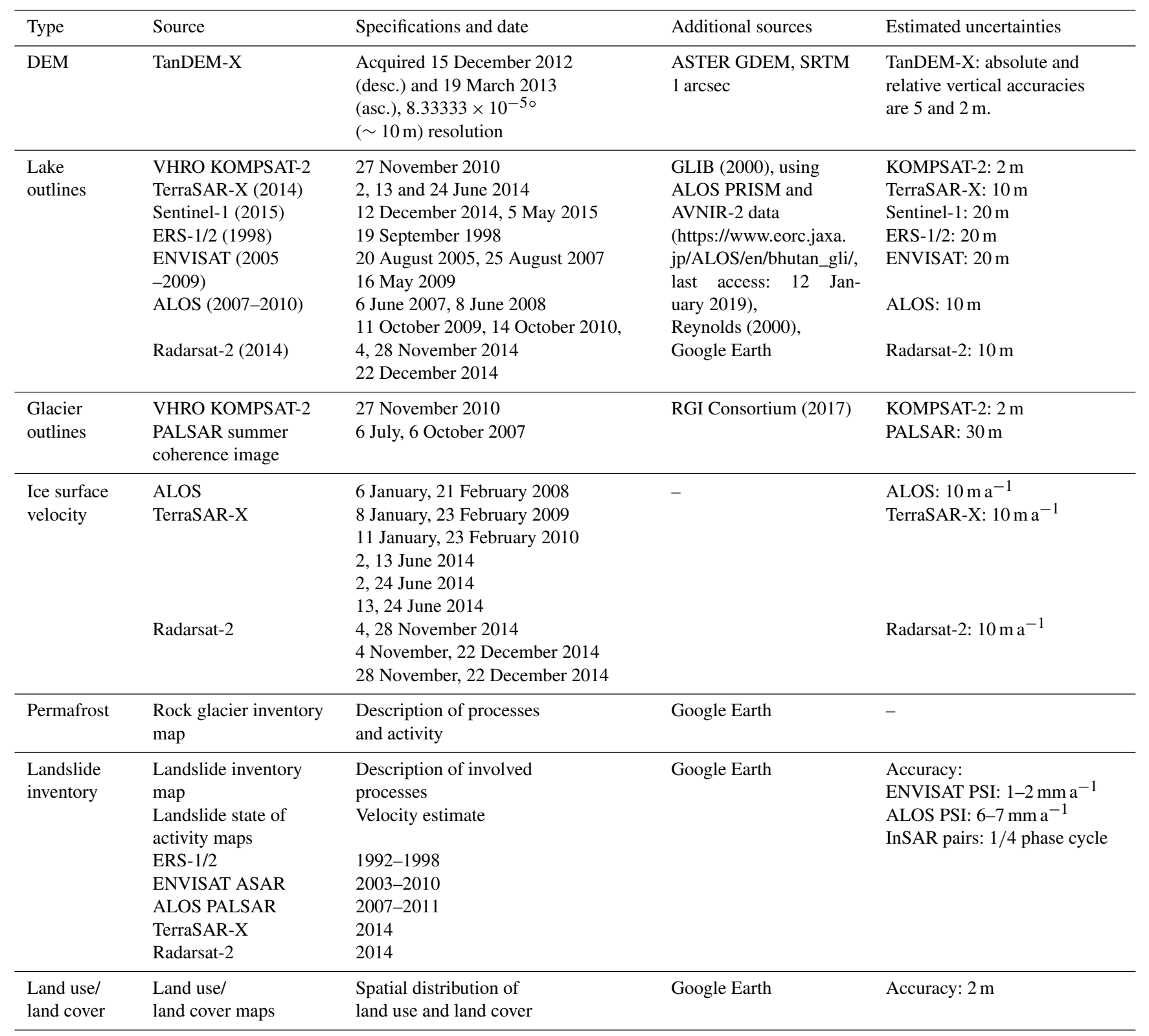

According to Huggel et al. (2002: 322), the lake volume can be doubled in the case of outbursts from moraine-dammed lakes:

$Q_{\max }=\frac{2 V}{t}$.

Finally, the minimum average slope for debris flows from lake outbursts $[\alpha]$, which conditioned the probable maximum travel distance of the debris flow, is a function of the maximum discharge [ $Q_{\max }$ ] (Huggel, 2004: 35):

$\alpha=18 \times Q_{\max }^{-0.07}$.

The second model adopted here is based on numerical modelling using a two-dimensional dam break flooding simu- lation and applying a GIS-embedded approach. Here we applied the numerical model r.damflood, a GRASS GISintegrated two-dimensional dam break model that solves the conservative form of the 2-D shallow water equations using a finite volume method (Cannata and Marzocchi, 2012). The intercell flux is computed by a one-sided upwind conservative scheme extended to a two-dimensional problem. Data used for the simulation include the DEM, reclassified land use to assign Manning's friction coefficient values and a dam-breach map indicating the depth of the dam after collapse (Table 2). 
Table 2. Input and output parameters of r.damflood model for estimating the area potentially inundated in case of a dam break. For more detail, see https://grass.osgeo.org/grass74/manuals/addons/r.damflood.html (last access: 19 December 2018).

\begin{tabular}{lll}
\hline Section & Remarks \\
\hline (a) Options & \\
\hline a.1 & Flow direction additional output flag & Aspect of TanDEM-X DEM \\
a.2 & Computational method & Dam break without hypothesis \\
a.3 & Computational time step & $0,001 \mathrm{~s}$ \\
\hline (b) Input options & \\
\hline b.1 & Elevation raster map (accounting for reservoir's bathymetry and dam elevation) & TanDEM-X DEM \\
b.2 & Lake water depth raster map (easily obtained with r.lake GRASS GIS module) & From empirical relationships \\
b.3 & Dam breach width raster map (decreased dam height due to failure) & From empirical relationships \\
b.4 & Manning's roughness coefficient raster map & Land cover raster map \\
b.5 & Simulation time duration & 7200 s [= 120 min] \\
\hline (c) Output options & \\
\hline c.1 & Time lag for outputs generation & 30s \\
c.2 & Additional instants for output map generation & Raster map \\
c.3 & Prefix for water depth output raster maps & Raster map \\
c.4 & Prefix for water velocity output raster maps & Raster map \\
c.5 & Maximum water depth output raster maps & Raster map \\
c.6 & maximum water velocity output raster maps & Raster map \\
c.7 & Maximum intensity output raster maps & Raster map \\
\hline
\end{tabular}

\section{Results}

\subsection{Satellite EO mapping}

Detailed geomorphological mapping is reported in Fig. 3. The areal extent data of the four main glacial lakes on and around the Thangothang Chuu glacier, derived from this mapping, are reported in Table 3. The slightly different values reported on the GLIB (2000) and our own mapping indicate a growth or shrinkage of the lakes between 2000 and 2010. The surface increase of lake Wa-007 is limited $(+4.0 \%)$ and rather negligible for Wa-006 $(+1.2 \%)$, whereas it was very important for Wa-008 $(+16.3 \%)$. In only one case are we in the presence of lake shrinkage, with a decrease of $8.4 \%$ for the Wa-009 lake surface.

The Wa-007 lake does not present evidence of important fluctuations of the water level, for example terraces and erosion scars in the freeboard. A visual comparison between five satellite images taken between 2006 and 2014 and visualized in Google Earth (Fig. 4) allowed the lake levels to be estimated on the basis of the width of the small island present in the south-western part of the lake. The island's extent was the largest on the oldest image (14 February 2006), indicating a low lake level rising until 2009 and 2010 (the two dates with the smallest island widths). In recent times, the lake level was the lowest in the observation period on January 2014 (largest measurement of the island width), reaching a width comparable to 2009 and 2010 in December 2014. It is nevertheless too simplistic to interpret such data as an increase in water

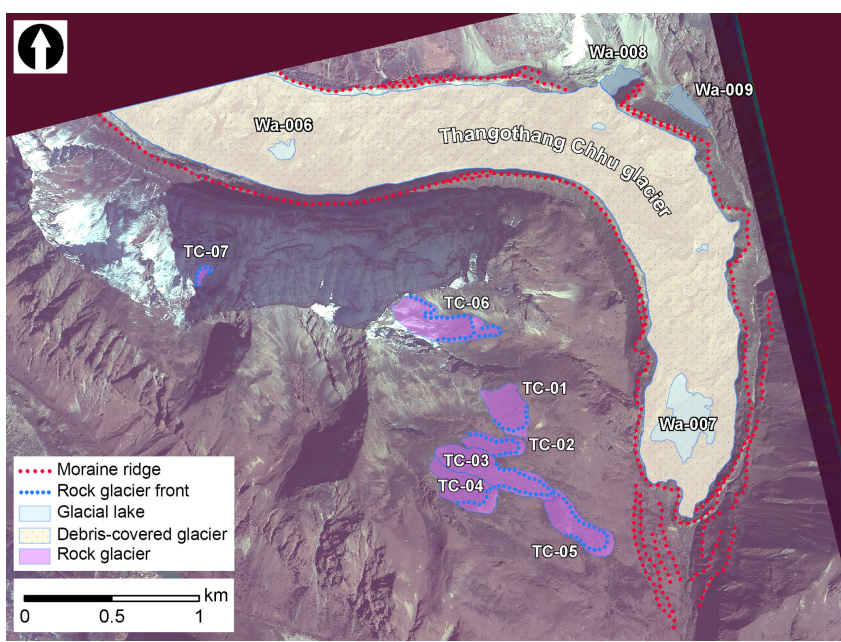

Figure 3. Glacial and periglacial landforms of the lower part of the basin of the Thangothang Chhu glacier. An active rock glacier is also present on the slope above lake Wa-009, but it is outside the frame of the image. Base map: VHRO KOMPSAT- 2 orthophoto from 27 November 2010.

level between 2006 and 2010, a decrease until the beginning of 2014 and a new increase. Considering the season of each analysed image, it is probable that the lower lake level in January and February compared to November and December is due to the lower specific runoff in consideration of the typical discharge regime of Himalayan glacier catchments (e.g. 
Table 3. Surface of the four main glacial lakes of the Thangothang Chhu glacier.

\begin{tabular}{|c|c|c|c|c|c|c|}
\hline \multirow{2}{*}{$\begin{array}{l}\text { Glacial } \\
\text { lake }\end{array}$} & \multirow[t]{2}{*}{ Type } & \multirow{2}{*}{$\begin{array}{l}\text { Elevation }^{1} \\
\text { (m a.s.l.) }\end{array}$} & \multicolumn{2}{|c|}{ Surface $\left(\mathrm{m}^{2}\right)$} & \multirow{2}{*}{$\begin{array}{r}\text { Surface } \\
\text { variation }(\%)\end{array}$} & \multirow{2}{*}{$\begin{array}{r}\text { Estimated } \\
\text { MAAT }\left({ }^{\circ} \mathrm{C}\right)\end{array}$} \\
\hline & & & $\begin{array}{l}\text { According to } \\
\text { GLIB (2000) }\end{array}$ & $\begin{array}{r}\text { This work (surface on } \\
27 \text { November 2010) }\end{array}$ & & \\
\hline Wa-007 & Supraglacial lake & 4330 & 88779 & 92308 & +4.0 & +0.5 \\
\hline Wa-006 & Supraglacial lake & 4600 & 11100 & 11228 & +1.2 & -1.1 \\
\hline Wa-009 & Ice-contact lake & 4462 & 25800 & 23637 & -8.4 & -0.3 \\
\hline Wa-008 & Ice-contact lake & 4470 & 17700 & 20589 & +16.3 & -0.3 \\
\hline
\end{tabular}

${ }^{1}$ From TanDEM-X DEM produced within this project.

Thayyen and Gergan, 2010). We can thus conclude that the lake level does not present important fluctuations so far.

As Wa-007 is a supraglacial lake, it is directly influenced by glacier dynamics. According to the TerraSAR-X images of 2 and 13 June 2014 (Fig. 5) and the ALOS PSI analysis (Fig. 6a), glacier velocities close to the lake are very low. This indicates a stagnant glacier, also explaining the very important cover in debris, which is the consequence of a positive balance between the accumulation of debris on the glacier surface and their evacuation by ice flow. Only the very steep upper part of the glacier moves with velocities larger than $100 \mathrm{~m} \mathrm{a}^{-1}$. Calving processes on the lake are possible, as shown by floating ice blocks on the 20 December 2014 image reported in Fig. 4. The detachment of small pieces of ice is also visible by the presence of several gullies on the ice-debris scarp dominating the northern side of the lake.

The dam of the supraglacial lake Wa-007 is composed of the debris-covered glacier itself: we can then consider it to be an ice dam. Just downstream of the glacier front, several moraine ridges are present (Fig. 3). In case of failure of the ice dam, these ridges can act as moraine dams because of their minimum altitude above lake level. Considering the kinematics of the glacier front, analysed by DInSAR from ALOS PSI and Radarsat-2 images, the ice dam of lake Wa007 is not stable and presents movements of several decimetres per year on the right side of the glacier (Fig. 6). The freeboard is between 2 and $5 \mathrm{~m}$ depending on the location. As the lake is not located directly close to the front of the debris-covered glacier, the width-to-height ratio of the dam is not critical. Considering that no morphological signs of surficial runoff from the lake are present (e.g. gullies), the freeboard is probably still sufficient to contain impact waves generated from ice falls. This is exclusively a morphological interpretation, because a numerical modelling of the possible run-up height of an impact wave (e.g. Schaub et al., 2015) has not been carried out. The lack of morphological signs also indicates that a surface outlet of the lake does not exist. Even in the absence of indications of percolation through the dam, it is probable that a percolation of water is present within the debris-covered glacier or, at least, at the contact between ice and the debris cover. As a consequence, the pos- sibility of a sudden drainage of the lake through the probably polythermal glacier should be considered.

In the lower part of the Thangothang Chhu glacier basin, eight rock glaciers were identified and mapped (Fig. 3). An assessment of their state of activity was performed based on ALOS and Radarsat-2 SAR interferometric analyses, which revealed significant surface displacements on the slope dominating the right side of the Thangothang Chhu glacier tongue (Fig. 7). The joint interpretation of the morphological characteristics and of the magnitude of movement allowed the differentiations between active (i.e. containing ice and moving downslope), inactive (i.e. containing ice but not moving) and relict (without ice) rock glaciers (Table 4), according to the conventional classification proposed by Barsch (1996). Only the rock glacier TC-05 can be considered to be a relict. This is located lower in altitude (from 180 to $280 \mathrm{~m}$ ) with respect to TC-2, TC-3 and TC-4, which present the same slope exposition. Rock glacier TC-6 is polymorphic sensu stricto (Frauenfelder and Kääb, 2000). The presence of two superimposed lobes is also visible in the kinematics of this complex landform, with the upper lobe that presents a magnitude of velocity higher than the lower one (Table 4). Estimated MAAT at the front of active or inactive rock glaciers is between -2.6 and $-0.8{ }^{\circ} \mathrm{C}$, whereas for the only relict rock glacier it is $+0.2^{\circ} \mathrm{C}$ (Table 3). Considering that the front altitude of the lowest active rock glaciers in a region allows for an estimation of the lower limit of discontinuous permafrost in loose debris (e.g. Barsch, 1996; Frauenfelder and Kääb, 2000; Boeckli et al., 2012), the presence of permafrost is probable above an altitude of $4600-4700 \mathrm{~m}$ a.s.l., corresponding to a MAAT of about -1.1 to $-1.7^{\circ} \mathrm{C}$. The occurrence of active rock glaciers on the right side of the Wa- 007 lake indicates a certain presence of permafrost in the catchment of the lake. Considering that the mapped rock glaciers are mainly exposed to the E and SE, and in accordance with the high-resolution permafrost zonation carried out by Gruber (2012), it is probable that the permafrost lower limit on north-exposed slopes may reach lower altitudes.

Except for Wa-006, all the lakes are located below $4600 \mathrm{~m}$ a.s.l.; therefore, according to the climate parameters presented above, MAAT at their elevation is between -1.1 and $+0.5^{\circ} \mathrm{C}$ (Table 3). As a consequence, for the two ice- 


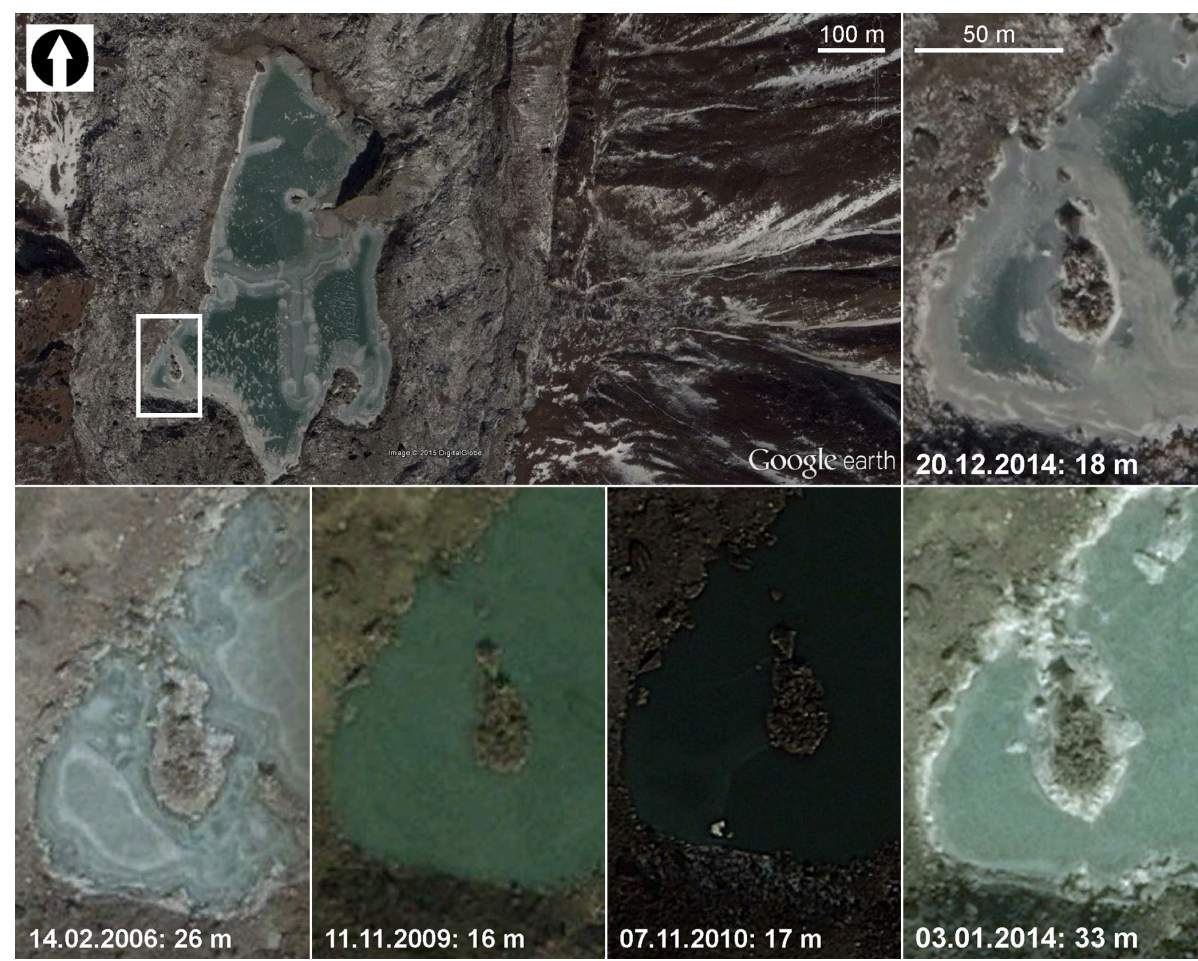

Figure 4. Google Earth images of the small island on the south-western part of the Wa-007 supraglacial lake (location of the white rectangle), used for a qualitative assessment of the lake level fluctuations.

Table 4. Topographical characteristics and magnitude of velocity of the rock glaciers located on the lower part of the Thangothang Chhu glacier basin. Name refers to the landforms mapped in Fig. 3.

\begin{tabular}{|c|c|c|c|c|c|c|}
\hline Name & $\begin{array}{l}\text { Degree of } \\
\text { activity }\end{array}$ & $\begin{array}{l}\text { Evidence of activity } \\
\text { (magnitude of velocity) }\end{array}$ & Exposition & $\begin{array}{r}\text { Front altitude } \\
\text { (m a.s.1.) }\end{array}$ & $\begin{array}{l}\text { Area } \\
\left(\mathrm{m}^{2}\right)\end{array}$ & $\begin{array}{r}\text { Estimated } \\
\text { MAAT }\left({ }^{\circ} \mathrm{C}\right)\end{array}$ \\
\hline TC-01 & active & $0-2 \mathrm{~cm} \mathrm{a}^{-1}$ by InSAR & SE & 4680 & 56747 & -1.6 \\
\hline TC-02 & inactive & $\begin{array}{l}\text { No evidence of activity, } \\
\text { but morphologically intact }\end{array}$ & $\mathrm{E}$ & 4660 & 35029 & -1.6 \\
\hline TC-03 & active & $0-2 \mathrm{~cm} \mathrm{a}^{-1}$ by InSAR & $\mathrm{E}$ & 4560 & 93744 & -0.8 \\
\hline TC-04 & active & $0-2 \mathrm{~cm} \mathrm{a}^{-1}$ by InSAR & $\mathrm{E}$ & 4660 & 66702 & -1.6 \\
\hline TC-05 & relict & $\begin{array}{l}\text { No evidence of activity } \\
\text { and morphologically relict }\end{array}$ & SE & 4380 & 68275 & +0.2 \\
\hline \multirow{2}{*}{ TC-06 } & \multirow{2}{*}{ active } & Upper lobe: $10-50 \mathrm{~cm} \mathrm{a}^{-1}$ & $\mathrm{E}$ & 4770 & \multirow{2}{*}{91202} & -2.1 \\
\hline & & Lower lobe: $2-10 \mathrm{~cm} \mathrm{a}^{-1}$ & $\mathrm{E}$ & 4850 & & -2.6 \\
\hline TC-07 & $\begin{array}{l}\text { active/ } \\
\text { inactive }\end{array}$ & No data & $\mathrm{N}$ & 4790 & 6838 & -2.2 \\
\hline
\end{tabular}

contact lakes partially dammed by moraine ridges (Wa-008 and Wa-009), the presence of permafrost on their dams is improbable. Despite this, it is nevertheless important to consider that the presence of dead ice, as well as the presence of very sporadic local permafrost conditions, is also possible several hundreds of metres below the lower limit of discontinuous permafrost.

Regarding unstable terrains identified upstream of the glacier lake, several landslides and rockfall deposits were mapped (Fig. 8). The state of activity of the mapped phenomena was evaluated from SAR interferometric data. A 


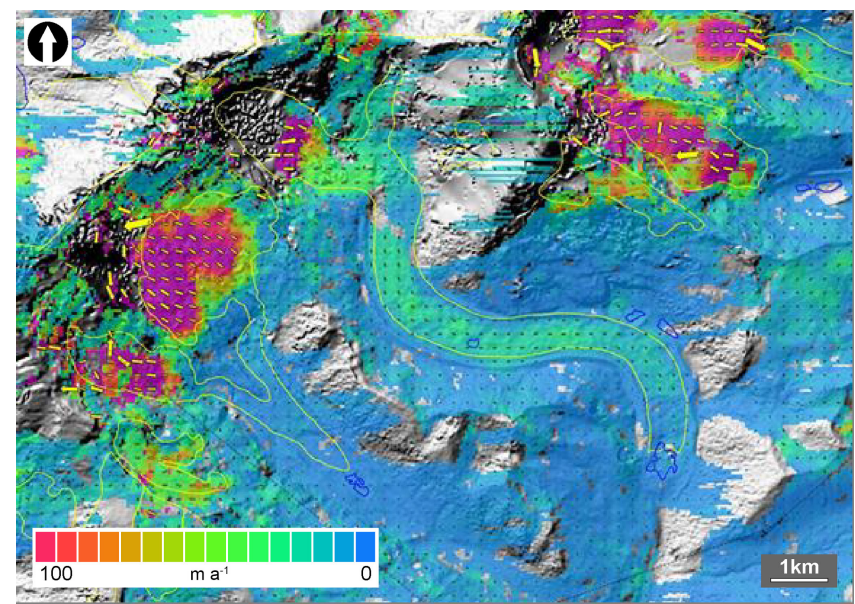

Figure 5. Horizontal ice surface velocity determined from TerraSAR-X images of 2 to 13 June 2014. Image background is a shaded relief of the DEM. Glacier boundaries (yellow) from RGI Consortium (2017). Lake boundaries (blue) from GLIB (2000).

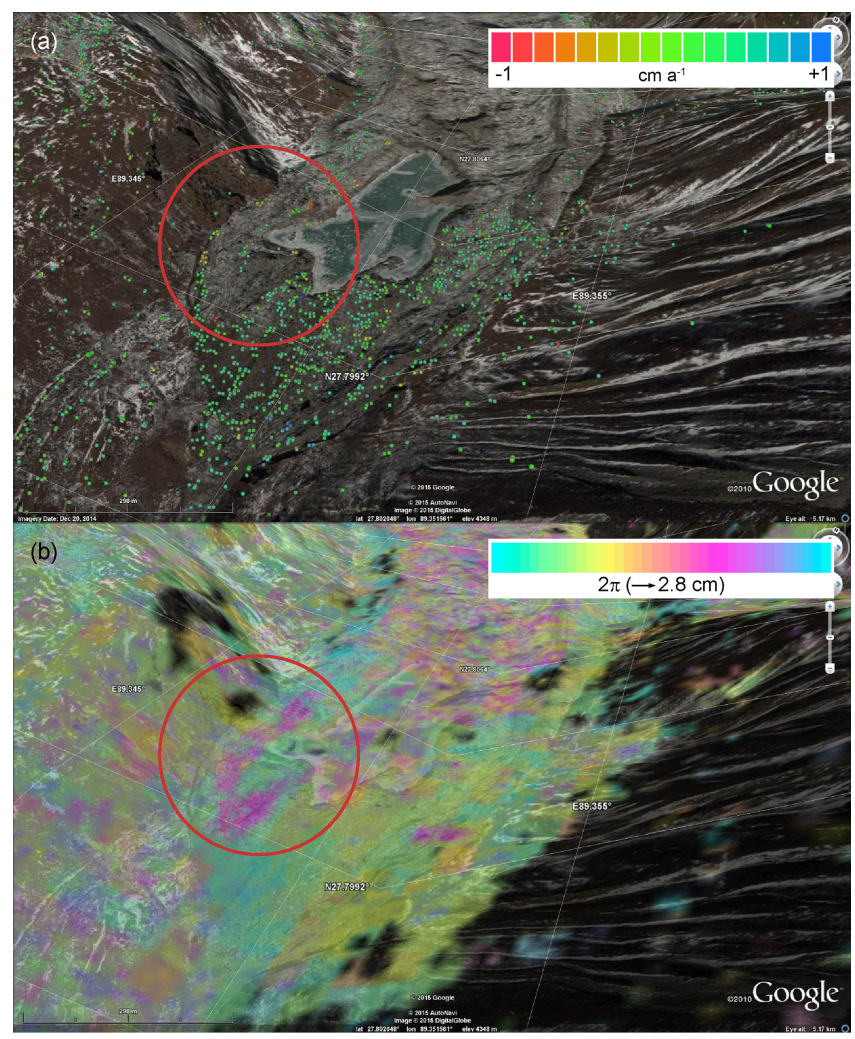

Figure 6. SAR interferometry of the debris-covered glacier tongue. (a) ALOS PSI between 18 February 2007 and 1 February 2011. Within the red circle the lack of points indicates that velocities might be higher than a few $\mathrm{cm} \mathrm{a}^{-1}$. (b) Radarsat-2 InSAR between 4 and 28 November 2014 (24 days). The signal is coherent, indicating a quite uniform movement with a rate between 10 and $50 \mathrm{~cm} \mathrm{a}^{-1}$. certain number of active soil slides affect in particular both lateral moraine ridges. Small rock slides are also present on the slopes above the glacier tongue. The movements of these slides are in all the cases of the order of magnitude of $1 \mathrm{~cm} \mathrm{a}^{-1}$ and cannot influence the stability of the Wa-007 lake. Small volumes of fractured rock mass were mapped in the area upstream of the glacier. These mapped volumes could evolve as rockfall but, in any case, they cannot influence the stability of the lake. In addition, areas of active erosion and areas affected by diffuse shallow landslides were recognized on the left slope above the glacier. Considering their limited volume and the phenomena restricted to the shallow surface, they do not represent a hazard factor for the stability of the lake.

The region of the lake itself is not directly exposed to eventual ice-rock avalanches related to hanging glaciers. These kinds of glaciers are, however, present in the upper part of the Thangothang Chhu glacier, with very steep slopes between 4800 and $6000 \mathrm{~m}$ a.s.l. and the fastest glacier velocities (Fig. 5). They can have an indirect effect on the Wa-007 lake in the case of major ice-rock avalanches related to the collapse of the main exposed part of these hanging glaciers (sectors with a pervasive presence of crevasses mapped in Fig. 8 as potential detachment zones of an ice avalanche), by causing a potential surge of the glacier related to a wave effect produced by the increase in load on the accumulation zone caused by the collapse of a hanging glacier (e.g. Gardner and Hewitt, 1990). However, as the lake is located at the middle of the glacier tongue, separated from the valley slopes by significant morainic ridges (Fig. 3), it is not directly subject to potential avalanches or rockfall trajectories. The presence of important moraine ridges provides a kind of natural protection from mass movement impacts from the lateral slopes for lakes Wa-006 and Wa-007 (but not for Wa-008 and Wa-009). The impact of ice-rock avalanches can, however, be important for lakes Wa-008 and Wa-009, located outside of the left lateral moraine ridge. Due to their position, these two lakes have a relatively high chance of being impacted by ice-rock avalanches. Deposits probably related to ice-rock avalanches are present in contact with these two lakes at the base of the slope.

\subsection{Hazard consideration}

Three other supraglacial lakes and two ice-contact lakes, not directly linked with the Wa-007 supraglacial lake, are present in the lower part of the Thangothang Chhu glacier catchment. The other supraglacial lakes are not sufficiently large to cause a GLOF and a subsequent debris flow impacting directly on the Wa-007 lake (the larger one is Wa-006, with a surface of $11100 \mathrm{~m}^{2}$ ). However, lake Wa-006 in particular can be a potential source of hazard for the Wa-007 supraglacial lake because, if it drains within the glacier, this could lead to a very rapid increase in the lake volume at $\mathrm{Wa}-007$ and cause drainage of this lake. The two ice-contact lakes present a 


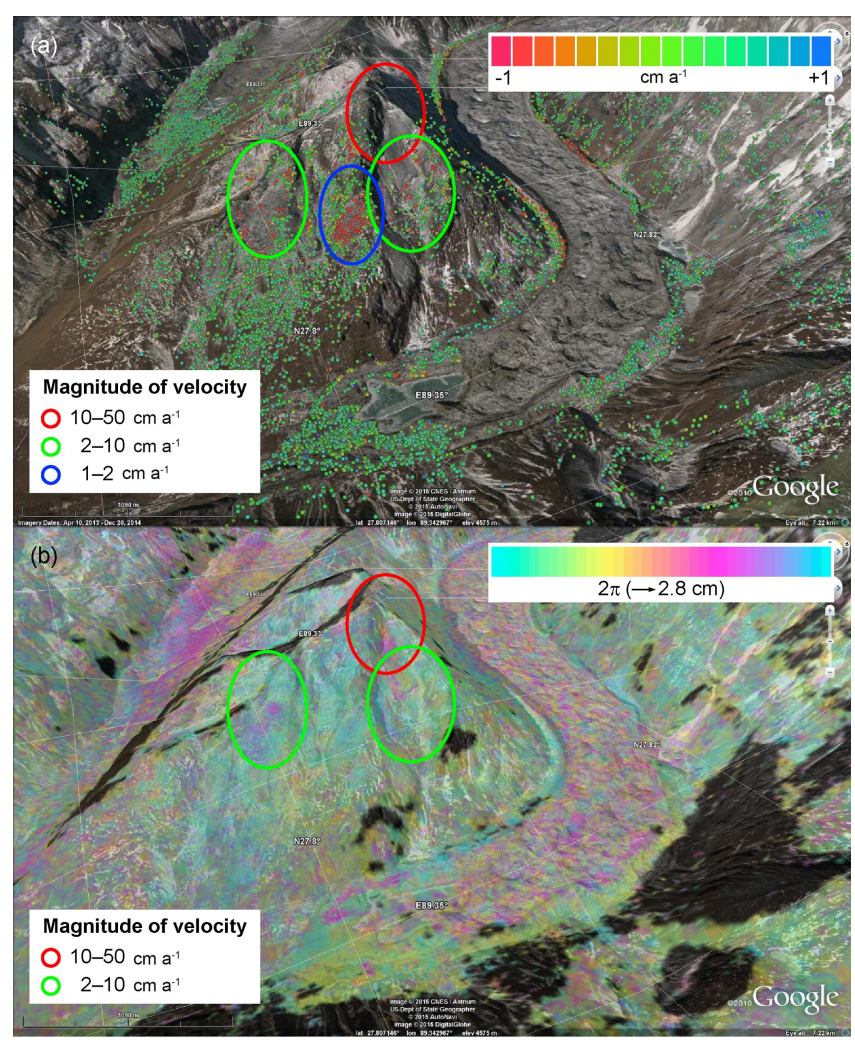

Figure 7. SAR interferometry of the slope dominating the Wa-007 supraglacial lake. (a) ALOS PSI between 18 February 2007 and 1 February 2011, with red points indicating velocities higher than $1 \mathrm{~cm} \mathrm{a}^{-1}$. (b) Radarsat-2 InSAR between 4 and 28 November 2014 (24 days). Unfilled ovals represent the magnitude of velocity for selected rock glaciers.

larger surface $\left(17700 \mathrm{~m}^{2}\right.$ for Wa-008 and $25800 \mathrm{~m}^{2}$ for Wa009), but an eventual debris flow related to a GLOF starting from these two lakes will be channelized between the left side of the valley and the left lateral moraine of the Thangothang Chhu glacier and not attend the Wa-007 supraglacial lake.

Considering the results of geomorphological mapping, the probability of (i) an ice-rock avalanche directly impacting the lake, (ii) large debris flows caused by GLOF related to the other glacial lakes located upstream, (iii) the presence of rapid landslides directly impacting the lake or (iv) very large lake fluctuations, appears to be low. As the flow velocities of the glacier around the lake are close to zero, a blockage of the subglacial drainage causing a rapid increase in the water level by intense precipitation or ice and snow melt is improbable. The main probable lake outburst trigger is related to the thinning of the ice dam related to important glacier retreat in the next years or decennia (significant ablation at the glacier front).

Another aspect that must be considered to be an outburst mechanism is a subglacial drainage by progressive enlargement of the subglacial channels within the glacier. This is

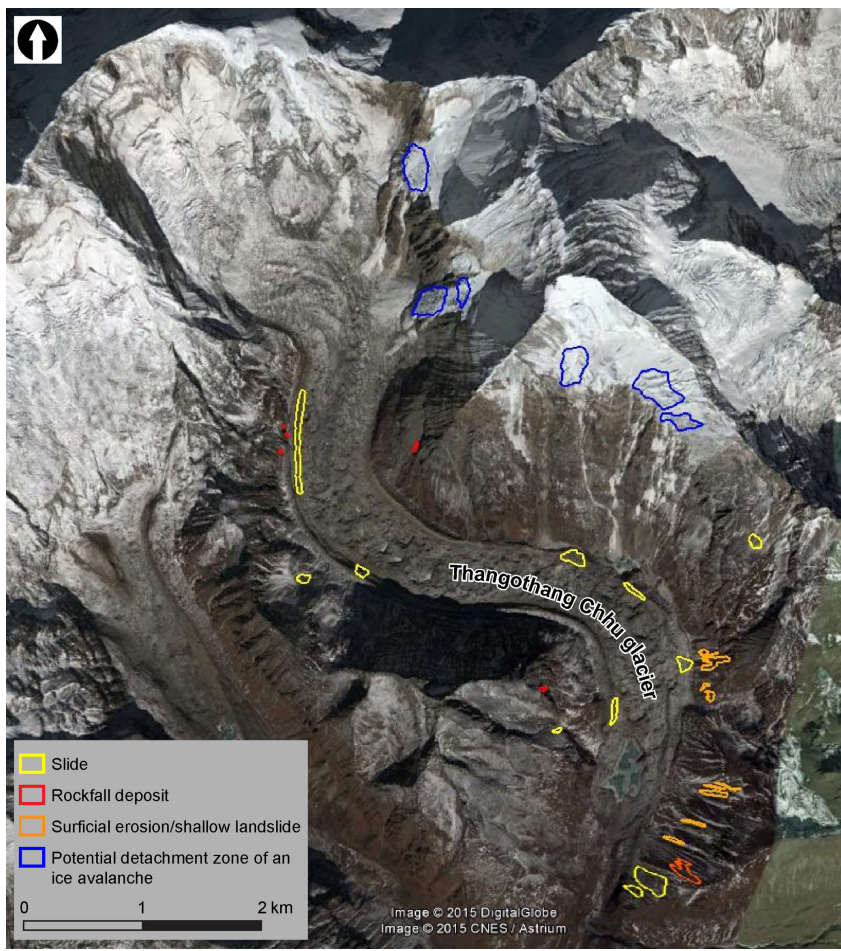

Figure 8. Google Earth image reporting a detailed inventory of landslides and other potential unstable areas present in the catchment of the Wa-007 lake excluding rock glaciers.

the most common drainage process for supraglacial lakes, as highlighted for the large supraglacial lake in 2002-2003 on Ghiacciaio del Belvedere above Macugnaga in Italy (Kääb et al., 2004) and in 2004 on a lake on the Gorner Glacier in the Valais Alps (Sugiyama et al., 2008). The connection between supraglacial lakes should not be forgotten. A potential drainage of Wa-006 lake within the glacier, for example, can lead to a very rapid increase in Wa-007 lake volume and therefore cause drainage of this lake. As a comparable situation, in June 2015 , only about $45 \mathrm{~km}$ north-east of the Chomolhari area, a GLOF happened: the drainage of a smaller lake caused an outburst of the lower lake (Palden, 2015).

Downstream of the Thangothang Chhu glacier tongue, abundant loose material is available, first by the presence of several frontal moraines and second by the presence of a glaciofluvial plain just outside of the historical moraines. However, considering that the main valley bottom presents an average slope of ca. $4^{\circ}$ and that the critical channel slope for erosion is about $8^{\circ}$ (Huggel et al., 2004), it is improbable that an eventual flood wave can transform into a debris flow. In other words, material deposition will occur on the first hundreds of metres downslope of the glacier front. Other lakes are not present downstream of $\mathrm{Wa}-007$ and the valley bottom is probably sufficiently large (100 to $300 \mathrm{~m}$ ) to prevent damming of the main river. 
Considering the situation during the time of this assessment procedure and the consequent current hazard evaluation described above, critical conditions triggering a GLOF from the Wa-007 supraglacial lake are probably not present. In future, therefore, radical modifications in the Thangothang Chhu glacier itself (in particular by glacial melting) or in the surrounding terrain (related to permafrost warming and ground ice thawing and activation and acceleration of shallow landslides and erosion zones) must to be considered as realistic. As a consequence, a worst-case scenario considering a complete rupture of the front of the glacier (ice dam failure) and a subsequent lake shrinkage was adopted for the modelling.

The results of empirical modelling are calculated, starting with a Wa-007 lake surface of $92308 \mathrm{~m}^{2}$ (Table 3). The mean lake depth calculated following Eq. (1) is $12.7 \mathrm{~m}$. Considering the scatter in regression presented by Huggel et al. (2002), however, the lake volume was quantified by adopting a mean lake depth of $15 \mathrm{~m}$. The resulting lake volume calculated by multiplying the lake area by the mean depth is $1384620 \mathrm{~m}^{3}$. For the ice dam it is necessary to use the hydraulic relationship proposed in Eq. (2). The probable maximum discharge in the case of subglacial draining of the icedammed lake is $57 \mathrm{~m}^{3} \mathrm{~s}^{-1}$. The maximum discharge increase significantly considering a sudden break of the ice dam; following Eq. (3), it is $1384 \mathrm{~m}^{3} \mathrm{~s}^{-1}$. As a consequence, the minimum average slope for debris flows from lake outbursts calculated following Eq. (5) is 13.6 and $10.9^{\circ}$ considering the maximum discharge calculated following Eqs. (2) and (3).

The results presented above include an extreme uncertainty because based on regressions providing mean-value statistics (Huggel, 2004). If we assume that a worst-case scenario must work with extreme values, the volume calculations are then based on a maximal mean value of lake depth. A very large uncertainty range is also present for the travel distance determined by the minimum average slope, which is based on a very large range of maximum discharge considering the diverse mechanics of breach formation. In the case of an outburst from moraine-dammed lakes, which is not the case for the Thangothang Chhu glacier, considering the estimated volume of lake Wa-007, the maximum discharge might even reach $2769 \mathrm{~m}^{3} \mathrm{~s}^{-1}$, as calculated according to Eq. (4). The subsequent minimum average slope is $10.3^{\circ}$. Even considering the scatter between these values, as the main slope of the valley floor is ca. $4^{\circ}$, the formation of a debris flow is highly improbable. As the channel slope is lower than $8^{\circ}$, considered to be a starting value for erosion (Huggel et al., 2004), it is assumed to only be the effect of a flood wave from the lake outburst.

The wave-front arrival time (Figs. 9 and 10), the maximum water height (Fig. 9) and the arrival time of maximum water height (Fig. 10) were simulated with the numerical model r.damflood. The results show that the wave front reaches

the Jantogang Camp in less than $1.5 \mathrm{~min}$ and the village of Jangothang ca. $3 \mathrm{~min}$ after the dam breach, corresponding to a maximal flow velocity between 23 and $28 \mathrm{~m} \mathrm{~s}^{-1}$. The maximum water height is reached at about $2.5 \mathrm{~km}$ distance from the lake (Fig. 9) in ca. 3 min (Fig. 10), corresponding to a mean flow velocity of $13.9 \mathrm{~m} \mathrm{~s}^{-1}$. Considering the lateral narrowing of the valley downslope of Jangothang, an estimation of about $10 \mathrm{~m}$ of water was simulated in that area. The only two human settlements reached by the simulated flood wave are Jantogang Camp and the village of Jangothang. In the first case, considering that Jantogang Camp is located about 5-6m above the Thangothang Chhu River bed, the maximum water height modelled is between 0.1 and $1.5 \mathrm{~m}$, which will reach this settlement less than 3 min after the ice-dam breaching and with a mean flow velocity higher than $11.7 \mathrm{~m} \mathrm{~s}^{-1}$. For Jangothang village, located in correspondence of a widening of the valley bottom, the maximum modelled water height is between $0.1 \mathrm{~m}$ on the upper part of the settlement and $4.5 \mathrm{~m}$ on its lower part, which is located on a fluvial terrace located only about 2-3 $\mathrm{m}$ above the river bed. In this case, the arrival time of the maximum water height is estimated between 4 and $8 \mathrm{~min}$, corresponding to a mean flow velocity between 8.8 and $17.5 \mathrm{~m} \mathrm{~s}^{-1}$.

\section{Discussion}

\subsection{Future evolution}

Considering a surface gradient of less than $2^{\circ}$ and further lowering of glacial surfaces indicating a thickness loss observed since the beginning of the 1960s on the glaciers of the Chomolhari area (Reynolds, 2000), we can expect a potential increase in area and volume in the Waa-007 lake due to glacier melting. This will also cause a probable change in the dam, by first modifying the dam width, and then the ratio between lake depth and ice thickness (Westoby et al., 2015). This normally determines the floating equilibrium: the subglacial channels typically start opening when the floating equilibrium is reached, also modifying the opening and close of part of the drainage network for meltwater due to modifications in the flow activity of the glacier (Bælum and Benn, 2011; Westoby et al., 2014). With an increase in glacier melting, we can also expect an increase in calving activity on the lake (Sakai et al., 2009).

In the accumulation zone of the Thangothang Chhu glacier, several hanging glaciers may warm in the next years or decennia and then pass from cold-based conditions to polythermal or even temperate-based conditions (Reynolds, 2000). Thus, their dynamics will accelerate and we can also expect an increase in the meltwater production (Thayyen and Gergan, 2010). This will then increase the probability of icerock avalanches in the upper part of the Thangothang Chhu glacier.

With a general increase in temperature and a modification in precipitation regime, we can also expect an evolution of 


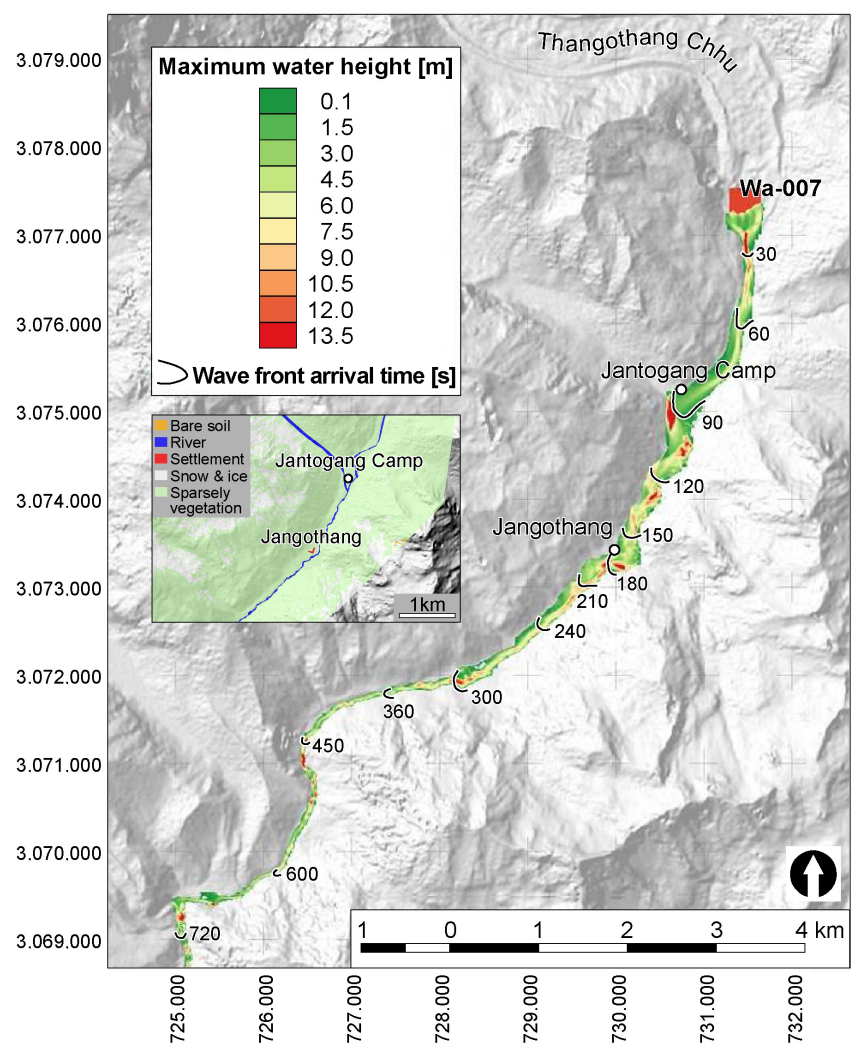

Figure 9. Wave front arrival time and maximum water height simulated with the r.damflood model for a complete collapse of the icedam of supraglacial lake Wa-007. In the box, a detail of the land cover map. Coordinates are expressed in WGS 1984 UTM zone $45 \mathrm{~N}$.

the mass movements affecting the slopes around the lake. Warming and partial thawing of permafrost ice can have an effect both on shallow landslides and on the flow velocity and stability of rock glaciers of the area (Daanen et al., 2012). With increasing water availability, we can expect a reactivation or an acceleration of shallow landslides and areas of erosion present on the left valley slope just above the Wa-007 lake (Ambrosi et al., 2018), with an increasing amount of sediment transfer toward the glacier tongue (although not directly in the lake itself). For rock glaciers, we can also expect a reactivation of inactive rock glaciers or an acceleration of active ones with the increasing temperatures of permafrost ice, as evidenced, for example, in the European Alps (e.g. Kääb et al., 2007; Delaloye et al., 2010; Scapozza et al., 2014).

As for the Wa-007 supraglacial lake, the GLOF hazard under current conditions is low, a long-term monitoring strategy based entirely on EO data is proposed (Table 5). With an update cycle of 5 years, this monitoring strategy has the objective of measuring the future developments of the lake to survey the evolution of glacier morphology and dynamics and to monitor the kinematics of the mass movements (including

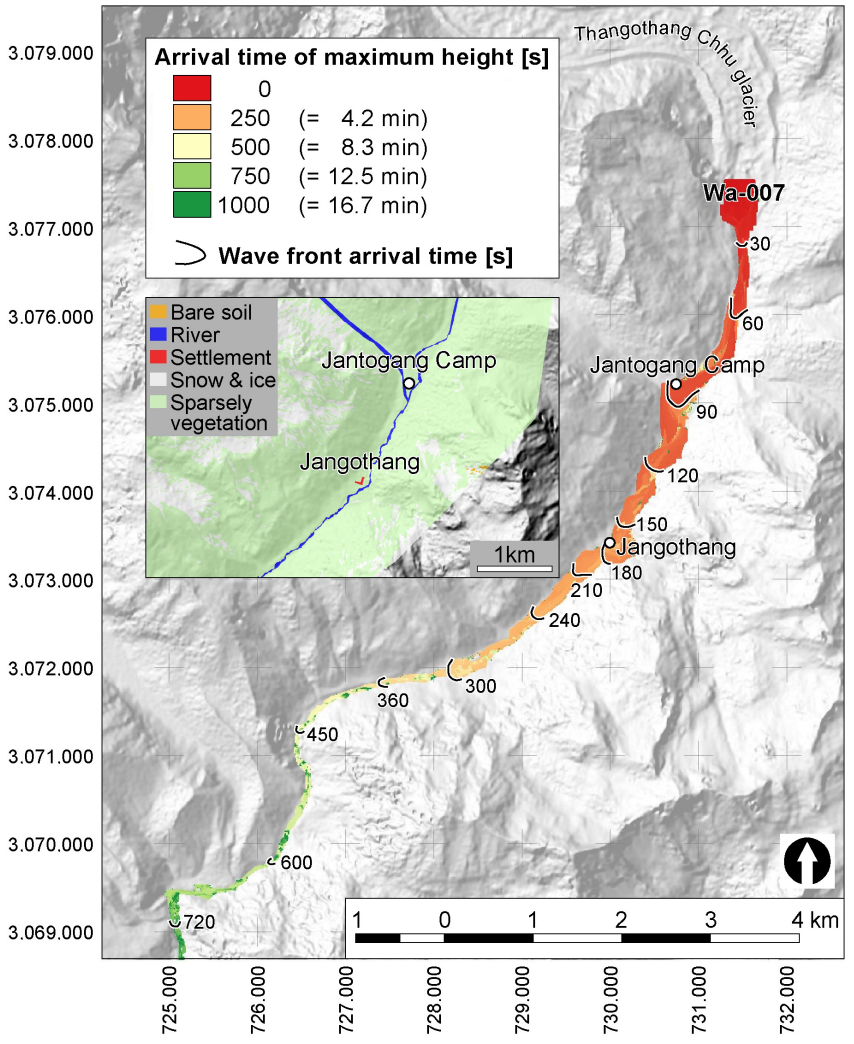

Figure 10. Wave front and maximum water height arrival times simulated with the r.damflood model for a complete collapse of the ice-dam of supraglacial lake Wa-007. In the box is a detail of the land cover map. Coordinates are expressed in WGS 1984 UTM zone $45 \mathrm{~N}$.

rock glaciers) surrounding the lower part of the Thangothang Chhu glacier catchment. Satellite EO alone will be normally sufficient for monitoring the evolution of this lake. However, as drainage variations are very difficult to detect by EO data, measuring the discharge at the glacier front might be very helpful to detect a GLOF event related to an increase in subglacial drainage by progressive enlargement of the subglacial channels within the glacier.

\subsection{Outburst scenario modelling}

The study was structured methodologically following the workflow proposed by Huggel (2004) and based on the integration of remote sensing and GIS modelling for the detection, assessment and detailed analysis of glacial hazards. Hazard assessment was based on EO mapping, terrain surface modelling (both for the production of DEMs and land cover maps) and determination of surface displacements from InSAR, according to the classical methodology applied for landslide hazard assessment based on EO data (e.g. Ambrosi et al., 2018 and references therein). Outburst scenarios were modelled by combining both empirical and numerical modelling, integrating detailed information from EO map- 
Table 5. Suggested future monitoring strategy for Thangothang Chhu glacier and supraglacial lake Wa-007, based on an update cycle of 5 years.

\begin{tabular}{ll}
\hline Data & Remarks \\
\hline $\begin{array}{l}\text { InSAR analysis; } \\
\text { Landslide inventory; } \\
\text { Rock glacier inventory }\end{array}$ & $\begin{array}{l}\text { PSI analysis with both ENVISAT and ALOS together with TerraSAR-X and Radarsat-2 InSAR data } \\
\text { gave useful results. Together with geomorphological mapping and geophysical remote sensing inves- } \\
\text { tigations, detailed information on the landslides, rock glaciers and hanging glaciers activity could be } \\
\text { obtained. A repeated landslide and rock glacier inventory (e.g. using Sentinel-1 and PALSAR-2 data) } \\
\text { will help anticipating new developments in due time. }\end{array}$ \\
\hline Ice surface velocity & Changes in glaciers velocities or surge. \\
\hline $\begin{array}{l}\text { Glacier outlines; } \\
\text { Lake outlines }\end{array}$ & $\begin{array}{l}\text { For documenting and monitoring the lake expansion and glacier retreat. In combination with the In- } \\
\text { SAR analyses and the landslide/rock glacier inventory, developments of new zones of potentially loose } \\
\text { material, exposed by glacier retreat, can be monitored. }\end{array}$ \\
\hline $\begin{array}{l}\text { Hanging glaciers } \\
\text { outlines }\end{array}$ & $\begin{array}{l}\text { For documenting and monitoring the hanging glaciers morphological evolution. In combination with } \\
\text { flow velocities derived from InSAR analyses, this allow a diachronical mapping of potential starting } \\
\text { zones for large ice avalanches coming from hanging glaciers. }\end{array}$ \\
\hline
\end{tabular}

ping, such as the dam characteristics, the loose deposits availability and the main slope (derived from the TanDEM-X DEM). Empirical model was applied to quantify the lake volume, the probable maximum discharge and the minimum average slope for debris flows from lake outbursts. This last parameter, compared with the effective topographical and morphological context of the Thangothang Chhu valley, allowed the most plausible scenario for numerical modelling to be defined. Based on these considerations, a debris-flow formation was thought to be very improbable in this hazard assessment. As a consequence, the applied numerical model was chosen only for the simulation of the flood wave from the lake outburst. This approach is particularly robust because, even if an empirical model can be perceived as relatively simplistic model, the geomorphological analysis and the subsequent hazard assessment is based on the detailed knowledge of the terrain characteristics (even if derived from EO). As a consequence, the GLOF numerical modelling, even if it is physically based and integrates the basic hydraulic principles that describe the mechanics of breach formation, represents only additional information about the entire process of hazard assessment and not a unique and unquestionable answer.

\section{Conclusions}

For Wa-007, the largest lake in the Thangothang Chhu glacier catchment, the likelihood of an outburst flood under the current morphoclimatical conditions appears to be low. The ice dam is, for the moment, relatively stable and sufficiently thick to prevent a dam breaching. The lack of morphological indicators at the surface of the glacier tongue also exclude lake overflowing because of a significant rise in the lake level, mass movements or ice collapse impacts on the lake.
Both empirical and numerical models indicate that a GLOF from Wa-007 lake is potentially dangerous, only when considering a worst-case scenario related to the complete collapse of the ice dam and then a subsequent almost complete emptying of the lake. This event is possible only under radical modifications of the glaciological conditions in the area: important ablation of the Thangothang Chhu glacier tongue, collapses of hanging glaciers located in the upper part of the catchment, which can originate large ice or icerock avalanches, or important acceleration and subsequent potential collapse of the rock glaciers and shallow landslides located directly upslope of the lake due to permafrost warming and thawing.

Model estimates revealed that a flood wave rather than a debris flow can impact the human settlements located downslope of Wa-007 lake. The formation of a large debris flow is very improbable because of the low inclination of the valley bottom. Under the worst-case scenario, the Jantogang Camp will be attained after less than $1.5 \mathrm{~min}$ from the ice dam collapse by a flood with a maximal water height between 0.1 and $1.5 \mathrm{~m}$, whereas the lower part of the village of Jangothang will be inundated by a maximum water height of $4.5 \mathrm{~m}$ about 4 to $8 \mathrm{~min}$ after the glacial lake outburst. Glacial lakes also exist in the next valley of the same catchment, but they have not been analysed. Consequently, this hazard analysis is incomplete for the involved village and is related exclusively to lake Wa-007.

The exclusive application of EO techniques allowed a detailed hazard assessment to be performed. Considering the remoteness of the Thangothang Chhu valley, a future monitoring strategy is also proposed based entirely on EO data, with the objectives of (1) detecting potential critical evolution of the glacial lake and of its surroundings, (2) surveying the Thangothang Chhu glacier and Wa-007 lake surface evolution, (3) assessing the hanging glaciers and slope instabil- 
ity evolution, (4) monitoring the kinematics of permafrostrelated landforms (rock glaciers) and of shallow landslides.

Data availability. Product description, metadata, guidelines for use and validation results, as well as EO data procurement, are available under http://repository.supsi.ch/10500/ (Sauerbier et al., 2015.).

Author contributions. CS performed the GLOF hazard assessment based on maps, data and interpretations provided by CA for landslide hazard assessment and evolution; MC carried out the numerical modelling of the flood wave from the lake outburst, and TS performed the InSAR data analysis and interpretation. CS prepared and revised the manuscript with contributions from all co-authors.

Competing interests. The authors declare that they have no conflict of interest.

Acknowledgements. ERS-1/2 SAR, ENVISAT ASAR, ALOS PALSAR and Radarsat-2 data were provided by the European Space Agency, courtesy of C1F.6504 and C1F.19889, CESA, JAXA and MDA, respectively. TanDEM-X data were provided by the German Aerospace Center (DLR), courtesy of Wegmulle_NTI_INSA3397, CDLR. TerraSAR-X data are courtesy of the EU FP7 CRYOLAND project, CDLR. We thank the European Space Agency for financial support (grant 4000110912-14-I-AM) and Martin Sauerbier (MFBGeoConsulting) for the pre-processing of the KOMPSAT-2 satellite optical data and for the production of land cover maps. The assessment report for GLOF hazard on the Chomolhari area, Bhutan, was revised by Philippe Bally and Holger Frey, whose comments were considered in the redaction of this manuscript. The manuscript was substantially improved thanks to Wilfried Haeberli, another anonymous reviewer and Christoph Graf as the handling editor.

Review statement. This paper was edited by Christoph Graf and reviewed by two anonymous referees.

\section{References}

Allen, S. K., Linsbauer, A., Randhawa, S. S., Huggel, C., Rana, P., and Kumari, A.: Glacial lake outburst flood risk in Himachal Pradesh, India: an integrative and anticipatory approach considering current and future threat, Nat. Hazards, 84, 1741-1763, https://doi.org/10.1007/s11069-016-2511-x, 2016.

Ambrosi, C. and Scapozza, C.: Improvements in 3-D digital mapping for geomorphological and Quaternary geological cartography, Geogr. Helv., 70, 121-133, https://doi.org/10.5194/gh-70121-2015, 2015.

Ambrosi, C., Strozzi, T., Scapozza, C., and Wegmüller, U.: Landslide hazard assessment in the Himalayas (Nepal and Bhutan) based on Earth-Observation data, Eng. Geol., 237, 217-228, https://doi.org/10.1016/j.enggeo.2018.02.020, 2018.
Bamler, R. and Hartl, P.: Synthetic aperture radar interferometry, Inverse Probl., 14, R1-R54, 1998.

Bælum, K. and Benn, D. I.: Thermal structure and drainage system of a small valley glacier (Tellbreen, Svalbard), investigated by ground penetrating radar, The Cryosphere, 5, 139-149, https://doi.org/10.5194/tc-5-139-2011, 2011.

Barsch, D.: Rockglaciers - Indicators for the present and former geoecology in high mountain environments, Springer, Berlin/Heidelberg, Germany, 331 pp., 1996.

Boeckli, L., Brenning, A., Gruber, S., and Noetzli, J.: A statistical approach to modelling permafrost distribution in the European Alps or similar mountain ranges, The Cryosphere, 6, 125-140, https://doi.org/10.5194/tc-6-125-2012, 2012.

Budhathoki, K. P., Bajracharya, O. R., and Pokharel, B. K.: Assessment of Imja Glacier Lake outburst Flood (GLOF) risk in Dudh Koshi river basin using remote Sensing Techniques, J. Hydrol. Meteorol., 7, 75-91, https://doi.org/10.3126/jhm.v7i1.5618, 2010.

Cannata, M. and Marzocchi, R.: Two-dimensional dam break flooding simulation: a GIS-embedded approach, Nat. Hazards, 61, 1143-1159, https://doi.org/10.1007/s11069-011-9974-6, 2012.

Daanen, R. P., Grosse, G., Darrow, M. M., Hamilton, T. D., and Jones, B. M.: Rapid movement of frozen debris-lobes: implications for permafrost degradation and slope instability in the south-central Brooks Range, Alaska, Nat. Hazards Earth Syst. Sci., 12, 1521-1537, https://doi.org/10.5194/nhess12-1521-2012, 2012.

Delaloye, R., Lambiel, C., and Gärtner-Roer, I.: Overview of rock glacier kinematics research in the Swiss Alps, Geogr. Helv., 65, 135-145, https://doi.org/10.5194/gh-65-135-2010, 2010.

Ferretti, C., Prati, F., and Rocca, F.: Permanent Scatterers in SAR Interferometry, IEEE T. Geosci. Remote, 39, 8-20, https://doi.org/10.1109/36.898661, 2001.

Frauenfelder, R. and Kääb, A.: Towards a palaeoclimatic model of rock-glacier formation in the Swiss Alps, Ann. Glaciol., 31, 281286, https://doi.org/10.3189/172756400781820264, 2000.

Frey, H., Kääb, A., Huggel, C., Wiesmann, A., and Strozzi, T.: S:GLA:MO Checklist for glacier lake hazard assessments V3.1, Department of Geography, University of Zurich, Switzerland, 7 pp., 2015.

Frey, H., Huggel, C., Bühler, Y., Buis, D., Dulce Burga, M., Choquevilca, W., Fernandez, F., García Hernández, J., Giráldez, C., Loarte, E., Masias, P., Portocarrero, C., Vicuña, L., and Walser, M.: A robust debris-flow and GLOF risk management strategy for a data-scarce catchment in Santa Teresa, Peru, Landslides, 13, 1493-1507, https://doi.org/10.1007/s10346-0150669-z, 2016.

Gardner, J. S. and Hewitt, K.: A surge of Bualtar glacier, Karakoram range, Pakistan: a possible landslide trigger, J. Glaciol, 36, 159_ 162, https://doi.org/10.3189/S0022143000009394, 1990.

GAPHAZ: Assessment of glacier and permafrost hazards in mountain regions - Technical Guidance Document, Standing Group on Glacier and Permafrost Hazards in Mountains (GAPHAZ) of the International Association of Cryospheric Sciences (IACS) and the International Permafrost Association (IPA), Zurich, Switzerland/Lima, Peru, 72 pp., 2017.

GLIB: Glacier and Glacial Lake Inventory of Bhutan using ALOS (Daichi) Data (Version 12.03), Japan Aerospace Exploration 
Agency (JAXA), available at: http://www.eorc.jaxa.jp/ALOS/en/ bhutan_gli/index.htm (last access: 2 March 2018), 2000.

Gruber, S.: Derivation and analysis of a high-resolution estimate of global permafrost zonation, The Cryosphere, 6, 221-233, https://doi.org/10.5194/tc-6-221-2012, 2012.

Gruber, S. and Haeberli, W.: Permafrost in steep bedrock slopes and its temperature-related destabilization following climate change, J. Geophys. Res., 112, F02S18, https://doi.org/10.1029/2006JF000547, 2007.

Gruber, S., Fleiner, R., Guegan, E., Panday, P., Schmid, M.-O., Stumm, D., Wester, P., Zhang, Y., and Zhao, L.: Review article: Inferring permafrost and permafrost thaw in the mountains of the Hindu Kush Himalaya region, The Cryosphere, 11, 81-99, https://doi.org/10.5194/tc-11-81-2017, 2017.

Haeberli, W.: Frequency and characteristics of glacier floods in the Swiss Alps, Ann. Glaciol., 4, 85-90, https://doi.org/10.3189/S0260305500005280, 1983.

Haeberli, W., Kääb, A., Vonder Mühll, D., and Teysseire, P.: Prevention of outburst floods from periglacial lakes at Gruben Glacier, Valais, Swiss Alps, J. Glaciol., 47, 111-122, https://doi.org/10.3189/172756501781832575, 2001.

Haeberli, W., Schaub, Y., and Huggel, C.: Increasing risks related to landslides from degrading permafrost into new lakes in de-glaciating mountain ranges, Geomorphology, 293, 405-417, https://doi.org/10.1016/j.geomorph.2016.02.009, 2017.

Haemmig, C., Huss, M., Keusen, H., Hess, J., Wegmüller, U., Ao, Z., and Kulubayi, W.: Hazard assessment of glacial lake outburst floods from Kyagar glacier, Karakoram mountains, China, Ann. Glaciol., 55, 34-44, https://doi.org/10.3189/2014AoG66A001, 2014.

Huggel, C.: Assessment of glacial hazards based on remote sensing and GIS modeling, Schrift. Phys. Geogr. Glaz. Geomorpho., 44, 1-75, 2004.

Huggel, C., Kääb, A., Haeberli, W., Teysseire, P., and Paul, F.: Remote sensing based assessment of hazards from glacier lake outburst: a case study in the Swiss Alps, Can. Geotech. J., 39, 316300, https://doi.org/10.1139/T01-099, 2002.

Huggel, C., Haeberli, W., Kääb, A., Bieri, D., and Richardson, S.: An assessment procedure for glacial hazards in the Swiss Alps, Can. Geotech. J., 41, 1068-1083, https://doi.org/10.1139/T04053, 2004.

Kääb, A., Huggel, C., Barbero, S., Chiarle, M., Cordola, M., Epifani, F., Haeberli, W., Mortara, G., Semino, P., Tamburini, A., and Viazzo, G.: Glacier hazards at Belvedere glacier and the Monte Rosa east face, Italian Alps, processes and mitigation, in: Proceedings of the 10th International Symposium INTERPRAEVENT 2004, Riva del Garda, Italy, 24-27 May 2004, 6778, 2004.

Kääb, A., Frauenfelder, R., and Roer, I: On the response of rockglacier creep to surface temperature increase, Global Planet. Change, 56, 172-187, https://doi.org/10.1016/j.gloplacha.2006.07.005, 2007.

Krautblatter, M., Funk, D., and Günzel, F. K.: Why permafrost rocks become unstable: a rock-ice-mechanical model in time and space, Earth Surf. Proc. Land., 38, 876-887, https://doi.org/10.1002/esp.3374, 2013.

Linsbauer, A., Frey, H., Haeberli, W., Machguth, H., Azam, M. F., and Allen, S.: Modelling glacier-bed overdeepenings and possible future lakes for the glacier areas in the
Himalaya-Karakoram region, Ann. Glaciol., 57, 119-130, https://doi.org/10.3189/2016AoG71A627, 2016.

Meteoblue: Climate Chomolhari, Paro, Bhutan, $27.82^{\circ} \mathrm{N}, 89.27^{\circ} \mathrm{E}$, 7314 ma.s.l., available at: https://www.meteoblue.com/en/ weather/forecast/modelclimate/chomolhari_bhutan_1252607, last access: 20 November 2018.

Nayar, A.: When the ice melts, Nature, 461, 1042-1046, https://doi.org/10.1038/4611042a, 2009.

Palden, T.: Experts find earthquake did not cause GLOF, Kuensel Online, available at: http://www.kuenselonline.com/ experts-find-earthquake-did-not-cause-glof/ (last access: $15 \mathrm{Au}$ gust 2018), 14 August 2015.

Paul, P., Bolch, T., Kääb, A., Nagler, T., Nuth, C., Scharrer, K., Shepherd, A., Strozzi, T., Ticconi, F., and Bhambri, R.: The glaciers climate change initiative: Methods for creating glacier area; elevation change and velocity products, Remote Sens. Environ., 162, 408-426, https://doi.org/10.1016/j.rse.2013.07.043, 2015.

Reynolds, J.: On the formation of supraglacial lakes on debriscovered glaciers, in: Debris-covered glaciers, edited by: Nakawo, M., Raymond, C. F., and Fountain A., IAHS Publication, 264, IAHS Press, Wallingford, England, 153-161, 2000.

RGI Consortium: Randolph Glacier Inventory - A Dataset of Global Glacier Outlines, Version 6.0, Technical Report, Global Land Ice Measurements from Space, Colorado, USA, https://doi.org/10.7265/N5-RGI-60, 2017.

Richardson, S. and Reynolds, J.: An overview of glacial hazards in the Himalayas, Quatern. Int., 65-66, 31-37, https://doi.org/10.1016/S1040-6182(99)00035-X, 2000.

Sakai, A., Nishimura, K., Kadota, T., and Takeuchi, N.: Onset of calving at supraglacial lakes on debris-covered glaciers of the Nepal Himalaya, J. Glaciol., 55, 909-917, https://doi.org/10.3189/002214309790152555, 2009.

Salzmann, N., Kääb, A., Huggel, C., Allgöwer, B., and Haeberli, W.: Assessment of the hazard potential of ice avalanches using remote sensing and GIS-modelling, Norsk Geogr. Tidsskr., 58, 74-84, https://doi.org/10.1080/00291950410006805, 2004.

Sauerbier, M., Baumgartner, M., Strozzi, T., Wiesmann, A., Ambrosi, C., and Scapozza, C.: ESA/WB collaboration on Satellite EO in the Himalayas (Nepal and Bhutan), Operational Documentation, eoworld - Earth Observation for Development, Frascati, Italy, 105 pp., available at: http://repository.supsi.ch/10500/ (last access: 27 March 2019), 2015.

Scapozza, C.: Assessment report for Glacial Lake Outburst Flood hazard on the Chomolhari area, Bhutan $\left(89^{\circ} 20^{\prime} 59.24^{\prime \prime} \mathrm{E} / 27^{\circ} 48^{\prime} 9.70^{\prime \prime} \mathrm{N}\right)$, ESA/World Bank collaboration on satellite EO in the Himalayas (Nepal and Bhutan), Frascati, Italy, 31 pp., 2015.

Scapozza, C., Lambiel, C., Bozzini, C., Mari, S., and Conedera, M.: Assessing the rock glacier kinematics on three different time scales: a case study from the Southern Swiss Alps, Earth Surf. Proc. Land., 39, 2056-2069, https://doi.org/10.1002/esp.3599, 2014.

Schaub, Y., Haeberli, W., Huggel, C., Künzler, M., and Bründl, M.: Landslides and new lakes in deglaciating areas: a risk management framework, in: The Second World Landslide Forum, Landslide Science and Practice, 7, edited by: Margottini, C., Canuti, P., and Sassa, K., Springer, Heidelberg, Germany, 31-38, https://doi.org/10.1007/978-3-642-31313-4_5, 2013. 
Schaub, Y., Huggel, C., and Cochachin, A.: Ice-avalanche scenario elaboration and uncertainty propagation in numerical simulation of rock-/ice-avalanche-induced impact waves at Mount Hualcán and Lake 513, Peru, Landslides, 13, 1-15, https://doi.org/10.1007/s10346-015-0658-2, 2015.

Schneider, D., Huggel, C., Cochachin, A., Guillén, S., and García, J.: Mapping hazards from glacier lake outburst floods based on modelling of process cascades at Lake 513, Carhuaz, Peru, Adv. Geosci., 35, 145-155, https://doi.org/10.5194/adgeo-35145-2014, 2014.

Strozzi, T., Luckman, A., Murray, T., Wegmüller, U., and Werner, C.: Glacier motion estimation using SAR offsettracking procedures, IEEE T. Geosci. Remote, 40, 2384-2391, https://doi.org/10.1109/TGRS.2002.805079, 2002.

Sugiyama, S., Bauder, A., Huss, M., Riesen, P., and Funk, M.: Triggering and drainage mechanisms of the 2004 glacier-dammed lake outburst in Gornergletscher, Switzerland, J. Geophys. Res.Earth, 113, F4, https://doi.org/10.1029/2007JF000920, 2008.
Thayyen, R. J. and Gergan, J. T.: Role of glaciers in watershed hydrology: a preliminary study of a "Himalayan catchment", The Cryosphere, 4, 115-128, https://doi.org/10.5194/tc-4-115-2010, 2010.

Westoby, M. J., Glasser, N. F., Brasington, J., Hambrey, M. J., Quincey, D. J., and Reynolds, J. M.: Modelling outburst floods from moraine-dammed glacial lakes, Earth-Sci. Rev., 134, $137-$ 159, https://doi.org/10.1016/j.earscirev.2014.03.009, 2014.

Westoby, M. J., Brasington, J., Glasser, N. F., Hambrey, M. J., Hassan, M. A. A. M., and Lowe, A.: Numerical modelling of glacial lake outburst floods using physically based dam-breach models, Earth Surf. Dynam., 3, 171-199, https://doi.org/10.5194/esurf-3171-2015, 2015. 